\title{
Benzedeiras: Lights and Shadows of the Religious Healing Practice in Brazilian Folk Catholicism
}

\author{
Renata Siuda-Ambroziak (iD) https://orcid.org/0000-0002-6594-0058 \\ American Studies Center \\ Institute of the Americas and Europe \\ University of Warsaw \\ e-mail: r.siuda@uw.edu.pl
}

\begin{abstract}
This article presents field research-based reflections on the socio-cultural contexts of religious healing practices in Brazilian folk Catholicism performed by traditional local blessing-givers (bendezeiras). Recognizing both illness and healing as socio-cultural processes and religion as an important key to understanding Brazilian culture and society, I concentrate on depicting important characteristics of the benzedeiras' practice, concentrating on "lights" (positive aspects) and "shadows" - adverse factors limiting the possibilities of intergenerational transmission in spite of the continuing popularity and symbolic effectiveness of benzedeiras' religious healing in Brazil.
\end{abstract}

Keywords: religious healing, popular Catholicism, benzedeiras, Brazil

Słowa kluczowe: religijne uzdrawianie, katolicyzm ludowy, benzedeiras, Brazylia

\section{From the fieldwork diary}

$5^{\text {th }}$ April, 2018. Brazilian inlands, rural area. I suddenly wake up in pain in the middle of the night to see my arm quickly swelling. The hospital is far away and heavy downpours have made it difficult to get around. The only alternative is a local benzedeira. An elderly lady opens the door, and carefully touches my swollen arm. She says it was a poisonous spider, but not the worst I could meet on my way and that I need to check my room well before going to sleep - especially in the heavy rains spiders like finding a cozy refuge. She gives me some strong herbs to drink and puts a strange, stinky ointment on the bite. She takes a rosary and a cross, prays for a few minutes, taps me with the cross on the swollen arm, whispering prayers and incomprehensible spells. Then she recommends digging a hole in the ground and putting 
my arm in there, tightly tamping down the soil around it. I lie down in the dark garden, comforting myself with the thought that, after all, at least it has stopped pouring and I am lucky enough not to have been bitten on the head... After some time I feel the soil loosening its grip around my arm. After a while I decide to dig it out. Dark fluid is streaming out of the bite. After a month there is just a little scar in its place.

$9^{\text {th }}$ June, 2018. A cold and rainy winter afternoon in Floripa. M. has just sneaked in through the back door with a bottle of wine. She sinks in the sofa, uncorks the bottle, pours the wine into glasses, smells it and approvingly nods her head. She has been recovering after skin cancer therapy and, simultaneously, a divorce. After a few glasses of wine, a story starts flowing... "It all started literally falling onto my head two years ago. I noticed skin problems. I went to see my dermatologist, and had an urgent surgery scheduled. I went back home and, exactly on the same day, my husband felt somehow compelled to tell me he was leaving... I broke down and called my Mom. She took me to her benzedeira - an elderly healer that used to cure us when we were kids. Again - she made my treatment successful and my recovery possible. She also told me wise things, slowed me down, in a positive sense. Now, although I am not really a churchgoer, I pay much more attention to spiritual things, I am more considerate with others, trying not to provoke anger, bad thoughts, or jealousy. I also do more things that give me and others some pleasure and that's why here I am, warming up your evening and soul with this spectacular wine. The thing that makes me somehow sad, though, is that my benzedeira is really old now. What I regret is that in the future if I happen to need her again..."

In Brazil I suffer from daily 'bombardments' with new topics, with new research adventures. I set off again, this time searching for benzedeiras to find out what they are all about, rather than looking for help for myself.

\section{Introduction}

Religion is one of the essential keys to approaching any culture, but in the case of Brazil, still so deeply religiously enchanted, it is simply a "must" for anyone who wants to understand it. Religion does not only give meaning to human life, suffering and death, but also successfully empowers, alleviates tensions and reinforces a sense of security, ${ }_{1}^{1}$ especially in situations seen as difficult, dangerous or boundary. An augmented need for religion appears especially when people experience a direct threat to life or health, and religious healing is among the most important reasons for people to convert. ${ }^{2}$

It is not always possible to scientifically interpret phenomena that take place at the intersection between religion, illness and health. ${ }^{3}$ Brazil's unofficial medical sys-

\footnotetext{
${ }^{1}$ P. Norris, R. Inglehart, Sacrum i profanum. Religia i polityka na świecie, trans. R. Babińska, Kraków 2006, p. 48.

${ }^{2}$ R. Siuda-Ambroziak, Jumping into Faith: The phenomenon of Brazilian Pentecostal Conversions, "Studia Religiologica" 2018, vol. 51, no. 1, pp. 11-32.

${ }^{3}$ While 'illness' refers to the experience and is identified with the perspective of the folk sectors of the health care system, 'disease' is tied to the professional sector and refers to the biological process.
} 
tem is closely related to popular religiosity with its deep syncretism and magic, the reasons why representatives of biomedicine often emphasize the ineffectiveness of religious healing practices (or treat them as harmful). ${ }^{4}$ Nevertheless, Brazilians, when confronted with health worries, continue searching for religion-oriented responses. One of them is provided by benzedeiras - traditional blessing-givers, whose craft is based on local popular Catholic religiosity, experience and common sense rather than any formal medical training or institutionalized expertise.

In this paper, interweaving biographies with socio-cultural context in order to show the characteristics, importance and vulnerability of the benzedeiras' practice, I intend to prove that high demand and common belief in the effectiveness of such healing and culture-oriented approaches to illness aimed at not only mitigating symptoms but finding their real causes and symbolic dimensions, does not guarantee continuation of the work of benzedeiras. Based on field research ${ }^{5}$ conducted in 2018, I will concentrate on both "lights" (positive aspects) and "shadows" (adverse factors) in the benzedeira tradition in the context of their daily 'healing chores' and 'recruitment policies', as well as the process of acquiring specialized knowledge.

I consider the topic important for several reasons: 1) the impact of popular Catholicism on the Brazilian society, in spite of decreasing official affiliations with the Church; ${ }^{6}$ 2) the scarcity of scholarly sources on the benzedeiras' craft, a result of the difficulty in approaching this local, oral-based practice; ${ }^{7} 3$ ) the special appeal of the Brazilian culture-dependent notions of the causes of illness related to religious issues; and 4) the popularity of religious healing, often helpful in cases where biomedicine seems to have no effect.

\section{Religious healing in Brazil}

Complementary and alternative medicine, including religious healing, constitutes a fertile field of research. ${ }^{8}$ However, in Brazil, religion and spirituality-oriented values, norms and beliefs are simply indispensable in understanding health-and-illness

I understand 'healing'/'therapy'/'treatment' as a human active response to illness. Cf. G.T. Lewith, Complementary and Alternative Medicine: An Educational, Attitudinal and Research Challenge, "The Medical Journal of Australia" 2000, March, vol. 172(3), pp. 102-103.

${ }^{4}$ Cf. B.B. O'Connor, D.J. Hufford, Understanding Folk Medicine, [in:] Healing Logics: Culture and Medicine in Modern Health Belief Systems, E. Brady (ed.), Boulder 2001, pp. 13-36.

${ }^{5}$ The research on various forms of religious healing in Brazil was a part of my post-doc project at the Federal University of Santa Catarina, Florianópolis. Cf. R. Siuda-Ambroziak, Benzedeiras em vias de extinção na Ilha da Magia, "Metis: História e Cultura" 2018, vol. 18, no. 34, pp. 125-146.

${ }^{6}$ According to the Brazilian Institute of Geography and Statistics (www.ibge.gov.br), affiliation with the Catholic Church has been falling: $1970-91.8 \% ; 1980-89 \%$; $1991-83 \% ; 2000-73.6 \% ; 2010-64.6 \%$.

${ }^{7}$ I have found very few monographs on benzedeiras' practices: E.A. de Pereira, N.P.M. Gomes, Assim se benze em Minas Gerais. Um estudo sobre a cura através da palavra, Belo Horizonte 2018; E.R. Oliveira, O que é benzeção, São Paulo 1985; Benza Deus! Benzedeiras em Curitiba: modernidade e tradição, V.A.G. Silva, J. Reinhardt, C. Juliana (eds.), Curitiba 2009.

${ }^{8}$ Cf. A. Bensoussan, Complementary Medicine- Where Lies Its Appeal?, "The Medical Journal of Australia" 1999, vol. 170, no. 6, pp. 259-262; I.D. Coutler, E.M. Willis, The Rise and Rise of 
related behaviors and delineating Brazilian culture-bound illness syndromes based on the system of representations explaining human relationships with the social and supernatural worlds. ${ }^{9}$ Different societies and cultures take care of their ill in different ways - in Brazil such care encompasses not only scientific medical knowledge, but also religious, "non-clinical" knowhow intended to benefit patients in the same way. What is interesting is that in different cultures not only can the same illness be perceived differently (or be even unknown), but the same symptoms can also be explained as provoked by completely different stimuli, often irrational, fitting into the local religious beliefs. ${ }^{10}$ In Brazil healers need to know how to effectively exorcise in cases of quite common evil spirit possession, invert bad luck or a spell deliberately cast on somebody by means of sorcery or black magic (a proverbial "illness or death by witchcraft" 11 or "vital energy loss" may occur as a result of severe trauma provoked by the certainty of having been cursed or doomed). Such beliefs are so widespread in Brazil that the wide range of religious healing sought by patients becomes indispensable for comprehending the whole system of representations in Brazilian society. ${ }^{12}$

In terms of determining the degree of success and efficacy of traditional, religionbased therapies, the fact that people continue to have recourse to such forms of treatment suggests that they produce some relevant, perceivable effects on human health and well-being. Religion plays an important psychotherapeutic role: it allows for building social bonds in the community, integrates, and reduces stress and tensions being a religious person can help boost immunity and alleviate pain. ${ }^{13}$ All that, not to mention the possibility of miracle healing, usually happening in a socio-cultural context well known to the patient. ${ }^{14}$ It is thus difficult to understand both illness and healing in isolation from a socio-cultural context which stimulates/inhibits restoring health. For instance, religious healing may occur by means of the cultivation of expectant faith through the personal influence of a healer transforming the meaning

Complementary and Alternative Medicine: A Sociological Perspective, "The Medical Journal of Australia" 2004, vol. 180 (11), pp. 587-589.

${ }^{9}$ E.J.M. Langdon, A doença como experiência: a construção da doença e seu desafio para a prática médica, Florianópolis 2009.

${ }^{10}$ N. Rodrigues, C. Caroso, A ideia de sofrimento e representação cultural da doença na construção da pessoa, [in:] Doença, sofrimento e perturbação: perspectivas etnográficas, L.F.D. Duarte, O.F. Leal (eds.), Rio de Janeiro 1998, pp. 137-150.

${ }^{11}$ Cf. W.B. Cannon, Voodoo Death, “American Anthropologist” 1942, April-June, vol. 44, no. 2, pp. $169-181$.

12 G.Velho, Projeto e metamorphose: antropologia das sociedades complexas, Rio de Janeiro 1994, p. 61; C.R. Brandão, Fronteira da fé-alguns sistemas de sentido, crenças e religiões no Brasil de hoje, "Estudos Avançados" 2004, vol. 18, no. 52, pp. 261-288.

${ }^{13}$ Cf. D. Hall, Religious Attendance More Cost-effective than Lipitor?, "Journal of the American Board of Family Medicine" 2006, no. 19, pp. 130-109; P.S. Mueller, D.J. Plevak, T.A. Rummans, Zaangażowanie religijne i duchowość a medycyna - sugestie dla praktyki klinicznej, "Rehabilitacja Medyczna" 2002, vol. 6, no. 3, pp. 57-66.

${ }^{14}$ P.H. Fry, G.N. Howe, Duas respostas à aflição: umbanda e pentecostalismo, "Debate e Crítica" 1975, July, no. 6, pp. 75-94. 
of an illness for the sufferer ${ }^{15}$ or by real impact of the healing ritual, including words, performance, and the use of symbols and images. ${ }^{16}$ Healing rituals, of which prayer and blessing are an essential part, can work regardless of space and time, in absentia or without the patient's knowledge. ${ }^{17}$

Benzedeiras base their knowledge on the locally acceptable cultural concepts and perceive illness in a much broader context than doctors do. Their reputation combines elements of beliefs, knowledge, skills, and an aura of religion-based, emotion-triggering symbols that raise the treatment-facilitating confidence of their patients. Religious healing is, therefore, not only a medical therapy - it is also a complicated experiential process that takes place in the context of local values, traditions, and religiosity, but it also practiced in a given social environment, susceptible to all sorts of transformations. The healing provided by Brazilian benzedeiras is no exception to the rule.

\section{The 'lights' of the benzedeiras' healing craft}

Benzedeiras, mostly elderly female healers, cater, for free, to the needs of all those in need - Catholics or not. They carry out rites, use herbs and say prayers and blessings and invoke spells against various health problems and misfortunes, deeply rooted in popular, syncretic Catholic religiosity and considered potent, especially in the case of certain illnesses of a "mixed" or purely "spiritual" character.

The social legitimacy of benzedeiras stems directly from their healing practice in distant rural inlands throughout Brazil, they are regarded as a very important reference in the field of public health. However, in the urban(izing) environment it seems to be a more vulnerable phenomenon, which I came to understand while observing and interviewing four benzedeiras (aged 83,77,71, 81) and four female members of their families from younger generations (daughters/granddaughters). ${ }^{18}$

All of these benzedeiras have families: two of them are married and two are widows; they have children and grandchildren and two of them have great-grandchildren. This is precisely what is expected of them in Brazilian folk culture: they should be married, have children, be rather poor but pious, religious, and knowledgeable in prayers, herbs and positive, sympathetic magic (good witchcraft). ${ }^{19}$ The ones I met fit such a popular image perfectly.

15 J. Frank, Persuasion and Healing: A Comparative Study of Psychotherapy, Baltimore, MD 1973.

${ }^{16}$ T.J. Csordas, The Rhetoric of Transformation in Ritual Healing," "Culture, Religion and Psychiatry" 1983, vol. 7, iss. 4, pp. 333-375; E.L. Schieffelin, Performance and the Cultural Construction of Reality, "American Ethnologist. Journal of the American Ethnological Society" 1985, December, vol. 12, iss. 4, pp. 707-724.

${ }^{17}$ L. Dossey, Prayer Is Good Medicine: How to Reap the Healing Benefits of Prayer, New York 1997.

${ }^{18}$ The citations from interviews are used in the text anonymously, according to the pre-established rules of contact with the informants. They have been translated into English by myself.

${ }^{19}$ E.R., Oliveira, op.cit., p. 25. 
According to some classic studies on traditional healers, ${ }^{20}$ they are usually recruited in one of three ways: either by divine selection (a dream of being chosen or a normative obligation in return for their own recovery from an acute or life-threatening illness), by their own choice to become an apprentice, or by means of a collective learning process organized through formal or informal networks between masters and neophytes. ${ }^{21}$ This last method is the least common in Brazil, where benzedeiras do not, generally, show any inclination to form associations or informal support groups. The only exception to their highly individualistic approach has occurred in the vicinities of Curitiba, ${ }^{22}$ where they have organized a grassroots movement for preservation and valorization of their craft, receiving accreditations from the Municipal Secretary of Health to exercise their profession and to organize training sessions, during which they share their knowledge and experience. ${ }^{23}$

The first of the mentioned groups, of those possessing "a divine gift," is most common to benzedeiras, who themselves believe deeply in the direct intervention of supernatural forces in their recruitment and practice:

It is a gift that God gave me. Other things-you can learn. The gift, no. You have to receive it from God and accept it. I was not eager at the beginning, but once you have a calling, you have no choice. It is not me who heals-God does. I am only a tool.

The gift came in my sleep. I woke up one morning and I knew what to do.

I went through problems with my spine when young. My grandma used to sit by my bed with a little cloth and a needle. She kept sewing every night, praying for my recovery. It was as if she was sewing my spine... And it worked. When she said I had a gift, I simply accepted it.

The gift needs activating through subconscious or voluntary learning of prayers, rituals and the usage of herbs. Sometimes the person is prepared in advance to start healing practice, but it may also happen spontaneously, in an "emergency situation" someone needs help, a benzedeira is unavailable and an "heiress" simply takes over, not even knowing that the gift had always been there, though sometimes unnoticed.

I received the gift and simply started making use of it, observing my grandmother at work.

${ }^{20}$ D. Joralemon, Altar Symbolism in Peruvian Ritual Healing, "Journal of Latin American Lore" 1985, vol. 11, pp. 3-29; V. Turner, The Forest of Symbols: Aspects of Ndembu Ritual, London 1967; M.M. Steedly, Severing the Bonds of Love: A Case Study in Soul Loss," "Social Science and Medicine" 1988 , vol. 27 , iss. 8 , p. 8416 .

${ }^{21}$ The first such case described by H. Ngubane, Body and Mind in Zulu Medicine: an Ethnography of Health and Disease in Nyuswa-Zulu Thought and Practice, London 1977.

${ }^{22}$ In 2018 a survey on benzedeiras was started in Feira de Santana, Bahia, where the local authorities intend to create a catalog, just as it was done in Paraná: Tourism Department Will Elaborate Catalog of Benzedeiras de Feira de Santana, http://www.feiradesantana.ba.gov.br/busca.asp\#links [access: 14.01.2019].

${ }^{23}$ Benza Deus!..., op. cit. 
My grandmother was a benzedeira. I accompanied her as a child. I liked it and simply absorbed it. I learned unintentionally.

I was the only kid in the family that was interested in what my mother was doing. I memorized well, repeated things. So it was natural my mother chose me, saying that I had a gift. And I was prepared to handle it.

When grandma died, my neighbor came up to me and asked to bless her ill son. I simply did it without much thinking. And it worked, so people started coming, I didn't notice when I took over.

The gift is always received for free, and benzedeiras must not trade it for anything. That is why they attend to all and do it for free, breaking the rules of the professional, biomedical health market:

I help but I never charge. I cannot stop healing, because if I stop, I get sick myself. If I can help, I cannot refuse. I cannot ask for anything, sell what I received for free.

I cannot imagine what it would be like to tell people to pay for it. God heals. Using me. And doing it for free, right?

I never charge for what I do. This is not about money...

Benzedeiras do not charge for their services, but people bring things voluntarily (in the past, food - today, money) which, although unpredictable and irregular, does contribute to the family budget:

You cannot ask for money, but if someone wants to leave something, that's different. Before, it was food: milk, meat, chicken, fruit. Now people usually leave money.

Sometimes people leave something, but you cannot say I do it for money.

I never ask for anything. But people feel grateful. They sometimes leave notes of 20, 50. Depends.

Benzedeiras believe that, having received their gift, they cannot cease to heal "until they leave the stage." None of them thinks of "retiring" from the service:

I wake up every day thanking God for the life he gave me. I'm not afraid of death, I know it will come. I feel happy with my life.

This gives meaning to life, gives strength... I love what I do.

It is good for you. You learn patience, you feel the presence of God. How could I want to stop doing it one day?

I have never thought about it in terms of work, profession, something you need to rest from, retire... I will stop when God decides I should stop it. Death comes naturally to everybody...

These benzedeiras are practicing Catholics, although one of them has some "Spiritist inclination." Nevertheless, they say that they heal in the name of the Christian God, with intermediation from Virgin Mary and Catholic saints. 
I am Catholic. I've always been. I am a devotee of the Virgin of Aparecida. To this day we have no one in the family who is not Catholic. Thank God.

I am formally a Catholic. But I sometimes attend the Spiritist Center with one of my daughters. It does no harm - they, after all, believe in the same God. They are also Christians.

Dealing with popular religious healings, scholars distinguish between therapeutic procedures (actions taken to solve the problem: prayers recited, saints invoked, symbolic object manipulated, herbs used); therapeutic outcomes (result obtained); and therapeutic processes, which, in the case of benzedeiras, consists of a specific ritual. ${ }^{24}$ In the office of blessing, spoken prayers (resulting from hybrid folk religiosity, a mixture of popular knowledge and various religious practices) are essential, the word itself being fundamental, but they also use herbs and various tools such as knives, scissors, needles, etc., which along with prayers allow healing to take place. In order for any popular cure to be effective, faith, trust and hope for healing should be demonstrated, interdependently and complementarily by three sides - the patients (belief in the power of the healer), the healer (belief in her own gift and techniques) and the social environment (the confidence of the whole social group in the effectiveness of healing) ${ }^{25}$ In the case of benzedeiras, in spite of the fact that they learn the craft and believe deeply in the gift they possess, they recognize themselves as complementary to, and not opposed to, the official biomedical health system. ${ }^{26}$ They all acknowledge that sometimes their prayers are not enough and when a disease is "of a doctor" and not "of a benzedeira" they advise patients to seek professional help or send them directly to the hospital, suggesting temporary remedies, if indispensable.

When asked about examples of the illnesses they treat, benzedeiras list some spiritual problems impossible to understand without the knowledge of Brazilian cultural context (for example an "open" or "fallen chest," an "evil" or "fat eye"), others, of physical character, caused by an inflammatory process (as headaches, migraines, stomach problems, colds) or external, physical injury due to various accidents (burns, bleeding, sprains, fractures). Many problems they treat are dermatological (rashes, acne, etc.) or psychological (e.g. excessive jealousy, family problems, relationship problems). In the majority of cases the symptoms either disappear or are relieved in a substantial way:

Doctors sometimes treat the body but do not treat the soul. But I try, if possible, to do both.

${ }^{24}$ W. Labov, D. Fanshel, Therapeutic Discourse, New York 1977; T.J. Csordas, A. Kleinman, The Therapeutic Process, [in:] Medical Anthropology. Contemporary Theory and Method, T.M. Johnson, C.F. Sargent (eds.), New York-Westport-Connecticut-London 1990, pp. 11-25; J.M. Janzen, Therapy Management: Concept, Reality, Process, "Medical Anthropology Quarterly. International Journal for the Analysis of Health" 1987, March, vol. 1, iss. 1, pp. 68-84.

${ }^{25}$ C. Lévi-Strauss, Antropologia Estrutural, trans. M. do Camo Pandolfo, São Paulo 2008.

${ }^{26}$ M. Grisotti, Sistemas médicos: Percepção e comportamento em relação ao processo saúde-doença em uma comunidade de Florianópolis (SC), "Política e Trabalho. Revista de Ciências Sociais" 2004, abril, no. 20, pp. 117-139. 
I never do what I am not able to do. I am not here to provoke problems. I am here to help. I will not do anything that might hurt.

Sometimes a person needs a doctor-and then I say it directly. And if I say so, people do what I tell them to do.

People often bring children, sometimes very small children. They cry, don't eat... a baby might have a fallen chest ("arca caída") or might have been bewitched by someone...

Benzedeiras themselves rarely need biomedical treatment:

If I have any problems, I drink herbal infusions. And it works.

I had 7 children, all of them born here. And I was fine. But now young people have a very stressful life, they get sick more easily. They open the body to evil things, which enter. None of my granddaughters gave birth naturally.

I am very well. If I get worse, I can help myself. Or tell my family how to help me. But I would go to the hospital, if I had to.

I do not fall ill easily. I take care of myself, of my body.

According to benzedeiras, the gift is "hereditary," passed on within the family to those who show a whole set of desired traits and abilities characteristic of the craft (deep religiosity, good memory, sensitivity, intuition, observational skills). In the context of knowledge transmission, all four benzedeiras mention difficulty in finding the right person to pass their craft on to, which in the past was not that problematic. Only one of the benzedeiras accepts the possibility of teaching someone from outside the family circle, although she recognizes the difficulties involved.

In my case, I can only pass it on to the family. It has always been like that. Unfortunately it is something that is finishing, I feel that young people no longer want to do it, to take over...

It must be someone from the family. But none of my children or grandchildren seems to be interested. This is not how it used to work in the past.

I still don't know who is going to take over when I die... But it should be someone from among the relatives. Sometimes people ask me how to do things, sometimes they write it, or even record it. But when I ask if they intend to cure people, they confess that they want to know in case they need it themselves. So what does it mean? That they want to keep it all in the drawer...

It is possible, I guess, to teach someone from outside the family. I might have to face it. Though it has always been a family thing-you grow with it and sort of breathe it at home.

Benzedeiras' problems in transmitting their healing skills is a recurring theme any prospective heiress has to receive and accept the gift and be ready to develop, learn and exercise it according to the rules. Let us see, focusing now on the shadows of the healing practice, why its transmission is becoming so difficult. 


\section{The "shadows" of the benzedeiras' healing practice}

The benzedeiras' craft, passed on from generation to generation, is now almost "on the verge of extinction" - none of them, to date, has found the right person within their circle of relatives to take over the mission. One of the reasons is the transmission pattern itself: in addition to the necessity to possess the "divine gift," a long learning process takes place, facilitated by the family environment. The ease and efficacy of transmission in the kinship line ${ }^{27}$ happens because knowledge needs absorbing through everyday exposure to the healing phenomenon, preferably since early childhood.

There are, obviously, some adverse factors of the benzedeiras' practice that may be considered potential impediments to the transmission process. I will concentrate on the most salient ones: changes in the characteristics of the socio-cultural environment where they act (due to urbanization; migrations; transformation of original, traditional community life; and the separation of nuclear families); changing educational and professional profile of young people in the families of the healers; the pro bono nature of the practice and the benzedeiras' stubborn non-compliance with the biomedical market economy; problems with privacy, commitment and availability; and, last but not least, being autonomous, shamanic-like figures with special, supernatural powers, representatives of a tradition-based Weberian model of legitimacy, ${ }^{28}$ benzedeiras are often condemned by people and institutions (such as Neo-Pentecostal pastors, dogma-oriented Catholic clergy and medical doctors) treating them as competitors in the field.

Some of these factors arise in the interviews with benzedeiras, others in conversations with their family members. Benzedeiras, when asked to comment on the adverse conditions of their healing practice, mention acknowledgment problems - in spite of the fact that they help for free and only when a diagnosis is not beyond their understanding or experience, and although doctors themselves happen to seek their help on issues that cannot be solved by biomedicine, they are criticized and mocked by some within the official healthcare system:

A doctor came here to ask for help. Nothing worked for the pains he had. I healed him with prayers and herbal infusions. It worked. Then he came with his son. It also worked ... but he said he couldn't admit it openly.

The blessing works for all who believe in it. Faith is fundamental. And it applies to everyone, also to the doctors, who sometimes appear here as well. Usually they ask me not to tell anyone, though.

Also brought up in the interviews is a negative effect of some recent socio-cultural changes due to migration processes: the influx of new people from outside of the original communities. The disappearance of the local, "native" culture, to which benzedeiras belong, can be seen as detrimental to the recognition of their practices. One

${ }^{27}$ E.A. de Pereira, N.P.M., Gomes, op. cit., p. 115.

${ }_{28}$ M. Weber, Economy and Society: An Outline of Interpretive Sociology, Berkeley 1978, pp. 11121135. 
of the them was "called names" by new neighbors, who accused her of "charlatanism"; another complained that she had been accused of harming people by neighbors who had recently moved in from São Paulo and told their children not to approach the house of the "witch."

One of the problems in terms of preserving the benzedeiras' craft is a growing Evangelical population in Brazil, openly condemning such practices:

Evangelicals call it sorcery or witchcraft, but my business is with God. One has to be of faith, of good intentions, I will never open my mouth to wish you evil, to curse you.

Many Evangelicals think it has to do with evil things. It takes a lot of stamina to continue. To be a healer is to do good, but there are a lot of people who confuse everything.

Now a lot of people come from outside. Their creed is different, even if they are Christians too. Without knowing it, they are afraid, they talk nonsense.

However, problems also exist within the Catholic environment. Two benzedeiras say they have had serious "misunderstandings" with local Catholic priests over their practices - one told a story of a local priest criticizing her work openly in the church during a sermon, another uses the word "persecution," speaking of the attitudes of some in the Catholic clergy and mentioning some problems that her family has been through because of her activity:

We go to Sunday mass, the whole family. And suddenly the priest begins to speak out against the benzedeiras, criticizing and speaking of "witchcraft." Everyone looks at me.

I have never spoken ill of the Church, of the priest. So why should the priest speak ill of me? He arranged to have lunch here with us one day. Everybody chatting happily and he suddenly turned to me and asked if, having such a beautiful family, I really needed to continue with my witchcraft...

Being a benzedeira means an obligation to resign from or set aside many other activities, including pleasurable ones. Obviously, this might be a serious deterrent for prospective heiresses.

If God gives you that gift, you must assume, but it is also something that holds you back, you have no freedom. Anytime someone may come to ask for help. Your life belongs to others. It's a commitment that you simply have to accept. (daughter, aged 48)

You do not have any private life. You help when you are needed. Sometimes it might be difficult, especially for the family. People come in the middle of the night. And you will not send them away. (daughter, aged 51)

Some "day-to-day" problems were mentioned, related to working "with no gratification," the lack of privacy in a home "full of strangers," availability and commitment: 
Everything 's voluntary. OK, she does it because she likes it. We accept it. She gets even some money, people leave it though she never asks for it. But how to evaluate her time, her effort, her fatigue, her constant commitment? (daughter, aged 48)

We sometimes get angry - there are always people coming. But she is perfectly happy with her life. Who wants to make such a commitment these days? You have to have a lot of strength, and it's literally for nothing. (granddaughter, aged 23)

I ask you honestly - she knows a lot, but how much is it worth? She works days and nights, always available, and receives practically nothing. My daughter asks: Grandma, if I become a healer, who is going to pay my bills? (daughter, aged 51)

In the conversations with possible heiresses of benzedeiras, other problems arise, related, for example, to their educational background and future professional plans:

Grandma has always thought of me. I think she sees me as the granddaughter who would adapt quickly. And I even want to learn something. I find it useful. In the future I will know how to help my family, what herbs to apply, how to pray. But to do it for anyone who comes in, just like she does and wants me to do it, I'm not going to sacrifice myself. I want to travel after graduating, should I become a benzedeira when I am an engineer? Why study, then? (granddaughter, aged 21)

I'll tell you one thing: the job is about to end. Imagine, me, in the future, graduating in medicine, how would you explain my entering into this benzedeira business? Just imagine me saying at the college what I do here, with my grandmother. How can a person with no formal qualifications cure patients? Sadly, it's a thing of the past. Maybe in deep rural areas, with no access to doctors. What is the future for someone who devotes their time to learning, memorizing all these prayers and earns nothing? So that's the way it works. Of course, this is nothing grandma should hear. (granddaughter, aged 23)

Although the people interviewed always make their choices on what should be told, omitted or re-interpreted, it seems that due to some of the mentioned factors the process of intergenerational transmission of traditional benzedeiras' healing has indeed entered a critical stage.

\section{Conclusions}

It is not easy to interpret phenomena happening in between the two spheres of the medical and the religious, where we are dealing with a broad repertoire of nonspecific mechanisms, such as beliefs, prayers, magic, miracles and mystery. However, with regards to popular religious healing practiced by benzedeiras, I mainly pondered over its basic characteristics and presentation of "lights and shadows" of the phenomenon influenced by a set of socio-cultural factors: relations between benzedeiras and the professional medical market, with the former offering non-remunerative services; attitudes towards benzedeiras expressed by people of various religious institutions (with a growing numbers of religious representatives putting healing practices at the 
very heart of their own proselytizing activity, and thus fighting their competitors); old and new perceptions of the notions of commitment, service and sacrifice; changing expectations of generations in terms of satisfaction, happiness, family, professional life; and urbanization processes and migratory flows and their local results.

The research, in spite of its limited scope, made it possible to point towards basic characteristics and the importance and vulnerability of benzedeiras' practice, showing them as representatives of a tradition that is slowly losing its grip on popular healing manifestations based on religion and treating illness as both physical and spiritual problem. This is happening not so much due to a lack of demand, but rather to problems in transmission.

The importance of benzedeiras goes, however, far beyond healing: they preserve memory and a religion-based cultural identity, thinking of their "job" not only as a "divine gift," but as also a "hereditary disease," a genetically transmitted "family mission." Benzedeiras' healing practices constitute an example of how religion actually works, generating palpable results, albeit difficult to critically test and quantify. As I attempted to show, cultural interpretations of origins of illness, its causes and nature determine how people react to them; it is the "non-clinical" perception of the problem and its roots that still attracts Brazilians to benzedeiras' religious healing, especially when their worries cannot be solved by suppression of pathological symptoms. However, there is also a "non-clinical" set of socio-cultural changes and transformations that make their healing practice more difficult, even though many Brazilians still opt for religion-oriented responses to illness, turning their health concerns over to the sacrum, directly, through individual prayer, or with a helping hand of intermediaries, among whom traditional benzedeiras, possessing the gift of God and healing for free, are still among the most respected.

\section{References}

Bensoussan A., Complementary Medicine - Where Lies Its Appeal?, "The Medical Journal of Australia" 1999, vol. 170, no. 6, pp. 259-262.

Benza Deus! Benzedeiras em Curitiba: modernidade e tradição, V.A.G. Silva, J.C. Reinhardt (eds.), Curitiba 2009.

Brandão C.R., Fronteira da fé - alguns sistemas de sentido, crenças e religiões no Brasil de hoje, "Estudos Avançados" 2004, vol. 18, no. 52, pp. 261-288.

O'Connor B.B., Hufford D.J., Understanding Folk Medicine, [in:] Healing Logics: Culture and Medicine in Modern Health Belief Systems, E. Brady (ed.), Boulder 2001, pp. 13-36.

Cannon W.B., Voodoo Death, "American Anthropologist" 1942, April-June, vol. 44, no. 2, pp. 169-181.

Coutler I.D., Willis E.M., The Rise and Rise of Complementary and Alternative Medicine: A Sociological Perspective, "The Medical Journal of Australia” 2004, vol. 180 (11), pp. 587-589.

Csordas T.J. The Rhetoric of Transformation in Ritual Healing, "Culture, Religion and Psychiatry" 1983, December, vol. 7, iss. 4, pp. 333-375.

Csordas T.J., Kleinman A., The Therapeutic Process, [in:] Medical Anthropology. Contemporary Theory and Method, T.M. Johnson, C.F. Sargent (eds.), New York-Westport-Connecticut-London 1990, pp. 11-25. 
Dossey L., Prayer Is Good Medicine: How to Reap the Healing Benefits of Prayer, New York 1997. Frank J., Persuasion and Healing: A Comparative Study of Psychotherapy, Baltimore, MD, 1973. Fry P.H., Howe G.N., Duas respostas à aflição: umbanda e pentecostalismo, "Debate e Crítica" 1975, no. 6, pp. 75-94.

Grisotti M., Sistemas médicos: Percepção e comportamento em relação ao processo saúde-doença em uma comunidade de Florianópolis (SC), "Política e Trabalho. Revista de Ciências Sociais" 2004, abril, no. 20, pp. 117-139.

Hall D., Religious Attendance More Cost-effective than Lipitor?, "Journal of the American Board of Family Medicine" 2006, no. 19, pp. 130-109.

Janzen J.M., Therapy Management: Concept, Reality, Process, "Medical Anthropology Quarterly. International Journal for the Analysis of Health" 1987, March, vol. 1, iss. 1, pp. 68-84.

Joralemon D., Altar Symbolism in Peruvian Ritual Healing, "Journal of Latin American Lore" 1985, no. 11, pp. 3-29.

Labov W., Fanshel D., Therapeutic Discourse, New York 1977.

Langdon E.J.M., A doença como experiência: a construção da doença e seu desafio para a prática médica, Florianópolis 2009.

Lévi-Strauss C., Antropologia Estrutural, trans. M. do Carmo Pandolfo, São Paulo 2008.

Lewith G.T. Complementary and Alternative Medicine: An Educational, Attitudinal and Research Challenge, "The Medical Journal of Australia" 2000, March, no. 172(3), pp. 102-103.

Mueller P.S., Plevak D.J., Rummans T.A., Zaangażowanie religijne i duchowość a medycyna sugestie dla praktyki klinicznej, "Rehabilitacja Medyczna" 2002, vol. 6, no. 3, pp. 57-66.

Ngubane H. Body and Mind in Zulu Medicine: An Ethnography of Health and Disease in NyuswaZulu Thought and Practice, London 1977.

Norris P., Inglehart R., Sacrum i profanum. Religia i polityka na świecie, trans. R. Babińska, Kraków 2006.

Oliveira E.R., O que é benzeção, São Paulo 1985.

Pereira E.A. de, Gomes N.P.M. de, Assim se benze em Minas Gerais. Um estudo sobre a cura através da palavra, Belo Horizonte 2018.

Rodrigues N., Caroso C., A ideia de sofrimento e representação cultural da doença na construção da pessoa, [in:] Doença, sofrimento e perturbação: perspectivas etnográficas, L.F.D. Duarte, O.F. Leal (eds.), Rio de Janeiro 1998, pp. 137-150.

Schieffelin E.L., Performance and the Cultural Construction of Reality, "American Ethnologist. Journal of the American Ethnological Society" 1985, December, vol. 12, iss. 4, pp. 707-724.

Siuda-Ambroziak R., Jumping into Faith: The Phenomenon of Brazilian Pentecostal Conversions, "Studia Religiologica" 2018, vol. 51, no. 1, pp. 11-32.

Siuda-Ambroziak R., Benzedeiras em vias de extinção na Ilha da Magia "Metis: História e Cultura" 2018, vol. 18, no. 34, pp. 125-146.

Steedly M.M., Severing the Bonds of Love: A Case Study in Soul Loss, "Social Science and Medicine" 1988 , vol. 27, iss. 8, pp. 841-856.

Tourism Department Will Elaborate Catalog of Benzedeiras de Feira de Santana, http://www. feiradesantana.ba.gov.br/busca.asp\#links [access: 14.01.2019].

Velho G., Projeto e metamorphose: antropologia das sociedades complexas, Rio de Janeiro 1994.

Weber M., Economy and Society: An Outline of Interpretive Sociology, Berkeley 1978. 